\title{
Factors regulating the recruitment of cyanobacterial and eukaryotic phytoplankton from littoral and profundal sediments
}

\author{
K. Rengefors*, S. Gustafsson, A. Ståhl-Delbanco \\ Limnology, Department of Ecology, Lund University, Ecology Building, 22362 Lund, Sweden
}

\begin{abstract}
Many phytoplankton species produce resting cysts, forming 'seed banks' on lake sediments until they germinate and provide inocula (recruitment) for future pelagic populations. We have addressed the question of whether the littoral or the profundal zone provides the inoculum for planktonic populations in a eutrophic and dimictic lake (Lake Erken, Sweden). Our hypotheses were that high temperature, light, and sediment mixing would enhance recruitment. Also, we hypothesized that recruitment from littoral sediments would be greater than from profundal sediments. In situ recruitment traps were utilized to compare littoral and profundal recruitment, while laboratory experiments were performed to analyze which factors were most important. Seven common taxa were investigated: Asterionella formosa (Bacillariophyceae), Ceratium hirundinella (Dinophyceae), Microcystis botrys, M. wesenbergii, Anabaena sp., A. solitaria, and A. lemmermannii (Cyanobacteria). Our main findings were that light and sediment mixing were the most important factors in triggering and enhancing recruitment in the laboratory. Temperature and sediment origin (littoral/profundal) had a significant effect on recruitment only for A. lemmermannii and C. hirundinella, respectively. The field experiments showed that recruitment at the littoral site was much higher than at the profundal site, where little or no recruitment occurred. Together, these results strongly suggest that littoral sediments in temperate lakes provide inocula for most phytoplankton populations, likely due to favorable light conditions and high sediment mixing.
\end{abstract}

KEY WORDS: Phytoplankton - Recruitment - Germination - Seed bank - Littoral sediments · Profundal sediments $\cdot$ Cysts $\cdot$ Resting cells

\section{INTRODUCTION}

Recently, there has been an increasing understanding and more wide-spread acceptance that different habitats in an aquatic ecosystem are tightly coupled (Schindler \& Scheurell 2002). Traditionally, both limnic and marine ecosystems are divided into benthos and pelagos, although in reality there are both functional and structural connections between the 2 (Boero et al. 1996). Planktonic organisms are in general discontinuous in the pelagic zone, i.e. there is a seasonal succession of species, and they are not present all the time in the water column. Instead, many phytoplankton and zooplankton have life histories including both a ben- thic resting stage and a planktonic stage (Fryxell 1983, Hairston \& Cáceres 1996, Hairston 1998).

Boero et al. (1996) strongly argued for the need to study plankton and benthos as a unified system, for taxonomic and ecological reasons. For instance, studies of seasonal phytoplankton blooms must take into account the role of resting propagules in addition to variations in nutrients and predation. A number of studies, especially in the 1990s, showed that many limnic and marine algal species have resting propagules that germinate and migrate into the water column. These include cyanobacteria (Barbiero \& Welch 1992), cryptophytes (Hansson et al. 1994), chrysophytes (Sandgren 1983), diatoms (Lund 1954, McQuoid \& 
Hobson 1995, 1996), dinoflagellates (Anderson et al. 1983, Dale 1983, Hansson 1996b, Rengefors 1998), euglenophytes (Olli 1996) and raphidophytes (Hansson 1996a).

Early on in the 1900s, Huber \& Nipkow (1923) and Lund (1954) showed that Ceratium hirundinella (Dinophyceae) and Melosira italica (Bacillariophyceae) had resting stages which were involved in the seasonal periodicity of these species. However, it was much later that the mechanisms, regulation, and importance of these life cycle transformations became of more widespread scientific interest. Within the field of harmful algal blooms of marine dinoflagellates, it is now widely accepted that resting propagules play an important role in initiating blooms (Anderson \& Wall 1978, Anderson et al. 1983, Dale 1983, Anderson \& Keafer 1985). The significance of resting stages as inocula for blooms have also been verified in freshwater algal bloom species, mainly cyanobacteria (Barbiero \& Welch 1992, Forsell \& Pettersson 1995, Head et al. 1999) and dinoflagellates (Heaney et al. 1983). Seasonal succession, that is, timing of the initial phase of population growth, is also regulated by germination of resting cysts, as has been shown for dinoflagellates (Rengefors \& Anderson 1998) and suggested for diatoms (McQuoid \& Hobson 1995).

A main focus on many studies has been to resolve which factors regulate germination (resting stage activation) and recruitment (migration to the water column) in the different phytoplankton species with resting stages. In this paper, germination refers to the process in which the dormant cell or cyst becomes active (rejuvenation, excystment, growth) while recruitment is the process in which the newly germinated cell migrates to the water column. Within the dinoflagellates, both internal factors (endogenous clock, mandatory dormancy) and exogenous factors (temperature, light) operate in tandem to determine timing of germination (Anderson et al. 1985, 1987, Anderson \& Keafer 1987, Rengefors \& Anderson 1998, Kremp \& Anderson 2000). Among cyanobacteria and diatoms, temperature, nutrients, and light have been shown to regulate germination (Hollibaugh et al. 1981, Barbiero \& Welch 1992, Hansson 1993, van Dok \& Hart 1997). Recently, Ståhl-Delbanco \& Hansson (2002) showed that bioturbation can enhance recruitment of akinete-forming cyanobacteria, and Kremp et al. (2003) found that depositfeeder gut passage may enhance germination of dinoflagellate cysts. Moreover, there are both abiotic and biotic factors that can prevent germination. Anoxia was shown to prevent germination in dinoflagellates (Rengefors \& Anderson 1998, Kremp \& Anderson 2000). Also, the presence of predators inhibited the recruitment of Gonyostomum semen
(Raphidophyceae) (Hansson 1996a) and dinoflagellates (Rengefors et al. 1998).

An important issue to be resolved is the actual site of the main recruitment. Hansson (1996a) and Sanderson \& Frost (1996) found the greatest recruitment of Peridinium species from shallow sites. Likewise, cyanobacteria appear to recruit almost exclusively from the littoral sediments (Forsell 1998, Head et al. 1999, Brunberg \& Blomqvist 2003, Karlsson 2003). On the other hand, field studies of dinoflagellate cyst distribution have shown that large potential seed banks are accumulated in the profundal zone, and that a large portion of these actually excyst (Heaney et al. 1983, Rengefors 1998). In Lake Erken, for example, cyst numbers were 10 times higher in the profundal sediments compared to the littoral (Rengefors 1998). Furthermore, Pollingher et al. (1993) found fewer viable dinoflagellate cysts in the littoral sediment than in the profundal.

We hypothesized that the main site for recruitment of phytoplankton is the littoral zone, due to higher temperature, more light, and more sediment mixing than at profundal sites. We also hypothesized that both the littoral and profundal sediment contain a viable potential seed bank and that in conditions conducive to germination, no differences would be observed between the two. Furthermore, we hypothesized that light, high temperature, and sediment mixing (bioturbation or physical resuspension) should enhance recruitment. The objective of our combined laboratory and field study was to determine experimentally (in the laboratory) whether the littoral zone represents the major recruitment area for phytoplankton with a benthic resting stage and verify this by studies in the field. Finally, our aim was to identify which of the abovementioned factors was the most important in the initiation and promotion of recruitment of resting cells and cysts.

\section{MATERIALS AND METHODS}

Sampling site. The temperate dimictic Lake Erken, situated in southeastern Sweden, was chosen for this experiment. The seasonal succession of phytoplankton in Lake Erken follows the patterns of the Plankton Ecology Group (PEG*)-model (Sommer et al. 1986, Blomqvist et al. 1994), thereby making it a suitable representative of deep, slightly eutrophic, and temperate lakes. Lake Erken is considered naturally eutrophic

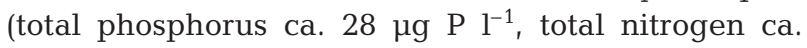
$657 \mu \mathrm{g} \mathrm{N} \mathrm{l}^{-1}$ ) (Weyhenmeyer 1999). The lake is normally ice-covered from December until April with an onset of the summer stratification at the end of May or beginning of June (Pettersson 1985). During late 
summer, Lake Erken is usually dominated by either a cyanobacterial community consisting of Gloeotrichia echinulata (J. E. Smith) Richter, Anabaena spp., Aphanizomenon spp., or by the dinoflagellate Ceratium hirundinella (O. F. Müller) Dujardin (Nauwerck 1963, Weyhenmeyer 1999). Diatoms, especially Asterionella formosa Hassall, may also contribute substantially to the phytoplankton biomass (Weyhenmeyer 1999).

The profundal site chosen for sediment sampling and recruitment traps was located at $14 \mathrm{~m}$ depth. The profundal region (12 to $20 \mathrm{~m}$ ) represents $31 \%$ of the lake area (Håkansson 1978). For logistical reasons (deepest diving depth) $14 \mathrm{~m}$ depth was chosen. A very shallow site located at $1.5 \mathrm{~m}$ was chosen to represent the littoral region. The 0 to $2 \mathrm{~m}$ depth interval represents $10 \%$ of the lake area (Håkansson 1978).

Laboratory germination experiment. Triplicate sediment cores ( $7 \mathrm{~cm}$ diameter) were sampled from the littoral zone (1.5 $\mathrm{m}$ depth) and from the profundal region of the lake (14 m) on 8 May 2001. Temperature loggers at the sampling sites recorded a temperature of 6.6 and $7.2^{\circ} \mathrm{C}$ at 14 and $1.5 \mathrm{~m}$, respectively. The top $2 \mathrm{~cm}$ were carefully sliced off and combined from 3 cores to minimize the effect of spatial variation, which was 15 to $20 \%$ by dinoflagellate cyst number in cores taken in proximity to each other in Lake Erken (Rengefors 1998). The sediments were stored in the dark at $4^{\circ} \mathrm{C}$ until the start of the experiment (29 June 2001). The reason for sampling the sediment in early May was to ensure that the samples contained a large and intact pool of resting stages from summer communities. In addition, by storing the samples in the dark for $7 \mathrm{wk}$, the risk of having vegetative cells grow rather than resting stages germinate was minimized. Gibson \& Fitzsimons (1990), for example, showed that Aulacoseira subarctica entered a physiological resting phase after 5 wk in the dark.

In order to determine which factors were most important in regulating germination from the lakes' sediments, a 2 by 4 factorial design was set up in the laboratory. The factors were sediment origin (littoral/ profundal), sediment mixing/no sediment mixing, light/dark (16:8 h LD cycle), and temperature $\left(7^{\circ} \mathrm{C} /\right.$ $17^{\circ} \mathrm{C}$ ). The light intensity was $100 \mu \mathrm{E} \mathrm{m}^{-2} \mathrm{~s}^{-1}$ from cool white fluorescent lamps. The 2 temperatures were determined based on the following: that the recruitment of Ceratium hirundinella is limited to temperatures above $7^{\circ} \mathrm{C}$ (Rengefors \& Anderson 1998), setting the lower range, and that summer temperatures of the littoral sediment is on average $17^{\circ} \mathrm{C}$ in Lake Erken, setting the upper range. Sediment mixing (physical resuspension or bioturbation) was mimicked by manual resuspension with a pipettor. By using manual resuspension of the sediments rather than bioturbating animals, we could avoid interspecific differences between different benthic organisms, avoid grazing by invertebrates, and perform the experiment in test tubes rather than aquaria.

There were 3 replicates for each treatment. Each replicate consisted of a Pyrex glass test tube (diameter $=21 \mathrm{~mm}$, area $=3.5 \mathrm{~cm}^{2}$ ) to which $5 \mathrm{ml}$ of sediments was added. Filtered $(0.2 \mu \mathrm{m})$ lake water was carefully added to the test tubes with a spray bottle in order to avoid resuspension of the sediment, except for the sediment mixing treatments, to which $20 \mathrm{ml}$ water was added vigorously with a pipettor. Tubes were subsequently placed in florists' foam, in order to submerge the part of the test tube with sediments, and only expose the sediment surface to light. All treatments were prepared in the dark using a red guide light only. The tubes were placed under a box covered with aluminum foil and black plastic. Sampling took place every $2 \mathrm{~d}$ in order to minimize reproduction of recruited organisms. Twenty $\mathrm{ml}$ of water was carefully removed with a pipette, taking care not to disturb the sediment. The samples were preserved with Lugol's solution for phytoplankton counts. The water was replaced by an equivalent volume of filtered aerated lake water (stored in the dark at 7 and $17^{\circ} \mathrm{C}$ ), using the spray bottle. The experiment ran for $18 \mathrm{~d}$ as most algae were expected to start recruiting within this time interval, based on data from previous studies (Rengefors \& Anderson 1998, Ståhl-Delbanco \& Hansson 2002). Aliquots of 5 to $20 \mathrm{ml}$ were counted in an inverted microscope at $100 \times$ magnification using settling chambers. Cell number was determined for monads and coccoid cells, while biomass was calculated for taxa that formed filaments or large colonies (i.e. Microcystis spp.), since they varied in size to a much larger extent.

The effect of the different treatments was analyzed statistically on the most common species using a multiway (4-way) ANOVA. Samples were counted and analyzed for all treatments on Day 8 only. This date was chosen from the time series, as a representative day when most species were recruiting (see Fig. 2). The ANOVA was performed after making a rank transformation of the data (Conover \& Iman 1981). This method was used because the data did not satisfy Levene's test of homogeneity necessary to perform variance analyses. Logistic regression was also used to determine which factor determined recruitment/no recruitment. No recruitment was transformed to category ' 0 ', while any recruitment regardless of size was denoted ' 1 '. The statistical package SPSS 10 was used for both analyses. The effect of time was analyzed on 2 combinations of treatments: littoral and profundal sediments with light, $17^{\circ} \mathrm{C}$, and sediment mixing. This combination of treatments was expected to yield the highest recruitment according to our hypotheses. The 


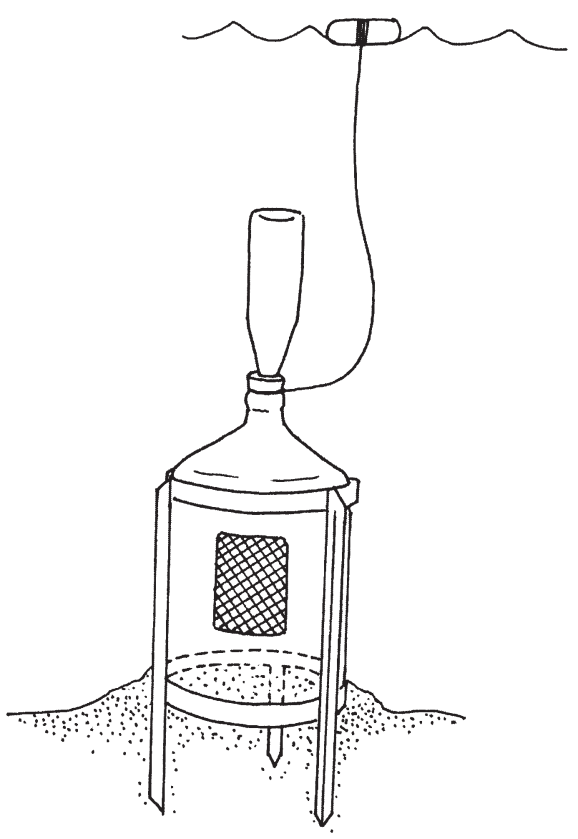

Fig. 1. Recruitment trap employed in the study

data were rank transformed as above and a repeated ANOVA was performed on each species using SPSS 10. Correlation of recruitment with time was analyzed using the nonparametic Spearman's Rank Correlation with the statistical package StatView.

Field recruitment. Recruitment in the field was tested on 3 occasions during the summer of 2001 using emergence traps. The emergence traps were designed after Cáceres (1998) and Hairston et al. (2000), and consisted of empty 191 transparent water bottles from which the bottom had been removed, totaling $530 \mathrm{~cm}^{2}$ in area (Fig. 1). Two rectangular holes were cut out on the side and covered with $40 \mu \mathrm{m}$ mesh, so that water could flow through the traps while larger plankton were excluded. A metal frame was placed on the bottom with 3 stainless steel bars protruding $30 \mathrm{~cm}$ into the sediment and the bottom of the traps were directly contacting with the sediment surface. At the mouth of the bottle, about $40 \mathrm{~cm}$ above the sediment surface, a 0.5 l Polyethylene Terephthalate (PET) clear plastic sampling bottle was attached upside down. The sampling bottles could be removed without removing the entire trap. From the neck of the water bottle a line extended with a small float to indicate the position in the water. Four emergence traps were placed at 1.5 and $14 \mathrm{~m}$ each several days previous to attaching the sampling bottles. The germination traps were not removed in-between sampling dates, only the sampling bottles were attached and removed on each occasion. By leaving the traps in the lake, resuspension leading to an apparent germination was avoided. Samples were collected on 12 to 13 June, 3 to 4 July, and 14 to 15 August. The PET bottles were filled with filtered lake water and attached by divers at the start of the experiment and then removed by divers after $24 \mathrm{~h}$. Due to the short sampling time we assumed that reproduction of recruited organisms as well as grazing from zooplankton inside the traps were minimal. The samples were preserved with Lugol's solution immediately after they had been returned to the surface. Aliquots of 5 to $25 \mathrm{ml}$ were counted in an inverted microscope at $100 \times$ magnification using settling chambers.

Light intensity data (photosynthetically active radiation [PAR], $\mu \mathrm{mol}$ photons $\left.\mathrm{m}^{-2} \mathrm{~s}^{-1}\right)$ and oxygen $\left(\mathrm{mg} \mathrm{O} \mathrm{O}_{2}\right.$ $\mathrm{l}^{-1}$ ) were retrieved from the Lake Erken monitoring program. Phytoplankton were sampled weekly at the deepest point in the lake $(20 \mathrm{~m})$ using volume-integrated composite samples, which were preserved with Lugol's solution. During periods of circulation the entire water column was sampled, while during stratification (6 June to 3 September) the epilimnion (usually 0 to $10 \mathrm{~m}$ ) was sampled. Phytoplankton were counted in an inverted microscope using settling chambers. Only phytoplankton analyzed in the recruitment traps are reported here.

The data were statistically analyzed by rank transforming the data (Conover \& Iman 1981) and then performing a repeated ANOVA using SPSS 10.

\section{RESULTS}

\section{Laboratory recruitment experiments}

Time effect

The effect of time on recruitment was statistically analyzed for the most abundant species including cyanobacteria, diatoms, and dinoflagellates. Within the cyanobacterial group, 2 chrooccocales (Microcystis botrys Teil and M. wesenbergii (Komárek) Starmach and 3 nostocales (Anabaena sp. 1, not identified to species level), A. solitaria Klebahn, and A. lemmermannii P. Richter) were most numerous. Asterionella formosa Hassall dominated the diatoms and Ceratium hirundinella (O. F. Müller) Schrank the dinoflagellates - Results on the cyanobacterium Gloeotrichia echinulata, which often dominates the late summer phytoplankton community in Lake Erken, have been reported in a separate paper (Karlsson-Elfgren et al. 2004).

The effect of time on recruitment resulted in 3 main patterns of response: a positive correlation of increased recruitment with time, a decrease of recruitment with time, and a group with an increase followed by a decrease. Anabaena sp. 1, A. lemmermannii, and 
Microcystis wesenbergii all had significant positive correlation with time (Spearman's Rank Correlation $\left[\mathrm{r}_{\mathrm{S}}\right], \mathrm{p}<0.05$ ) (Fig. 2, Table 1). Some species (e.g. Anabaena sp. 1) started recruiting immediately and continued throughout the entire time period. Others, such as $A$. lemmermannii and $M$. wesenbergii, did not
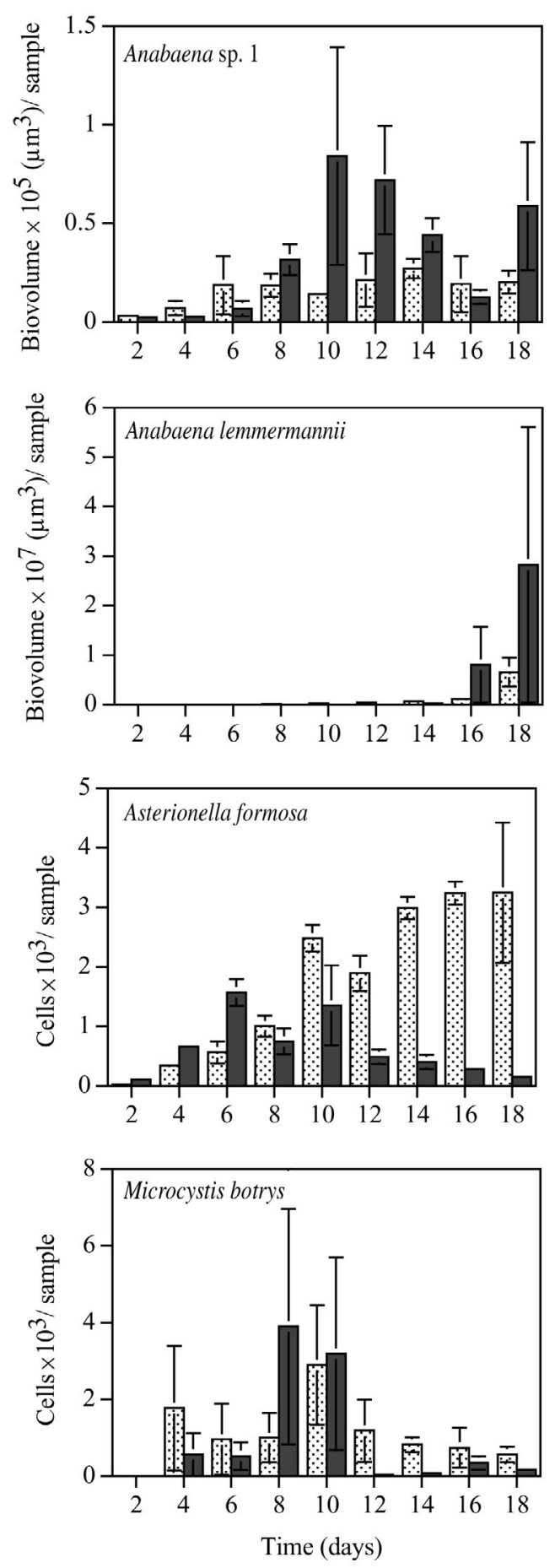

start recruiting until halfway through the incubation period. In contrast, Ceratium hirundinella and A. solitaria had the largest recruitment at the beginning of the incubation period, and significant negative correlations with time in profundal sediment samples (Fig. 2, Table 1).
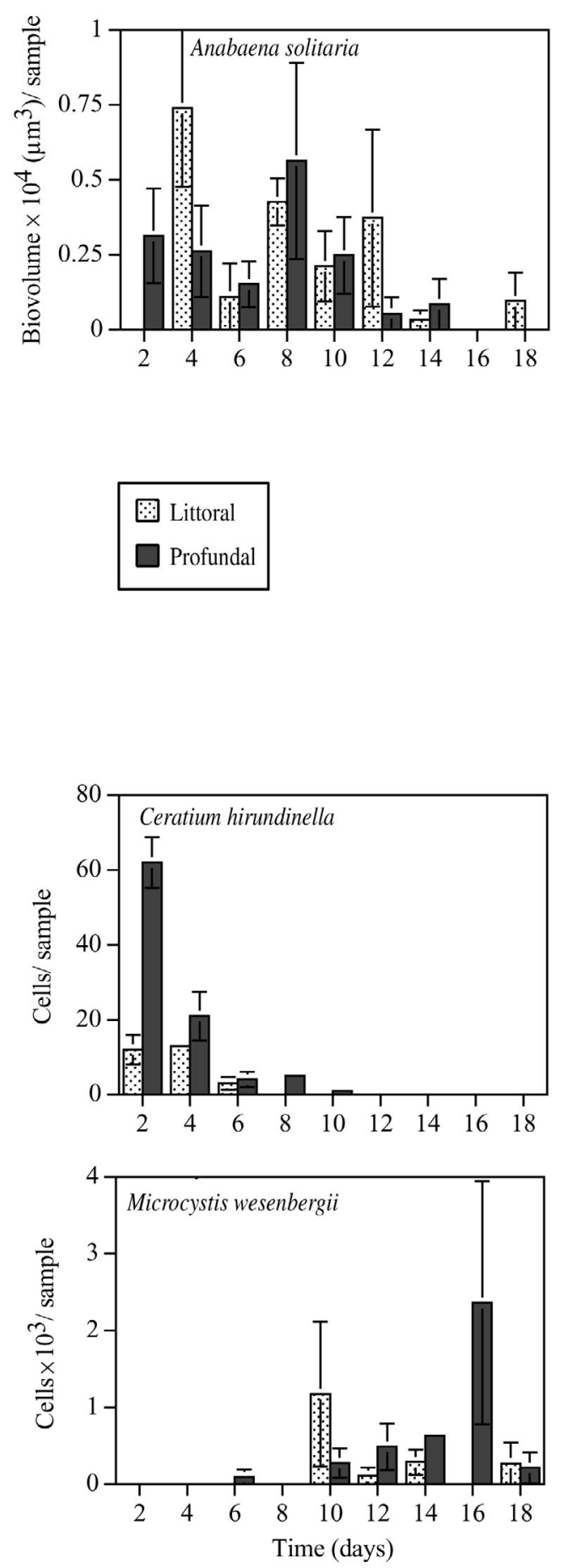

Fig. 2. Time series of recruitment from littoral and profundal sediments in treatments with light and $17^{\circ} \mathrm{C}$. Recruitment is illustrated either as biovolume (for filamentous species) or as cell number per sample. Error bars denote SE 
Table 1. Recruitment in different species correlated with time, shown for littoral and profundal sediments. Correlation analyses were performed using Spearman's Rank Correlation $\left(\mathrm{r}_{\mathrm{S}}\right)$ of non-parametric data on the time course recruitment experiment. Profundal and littoral sediment types were compared in a repeated (Rep.) ANOVA on rank transformed data. ns: not significant

\begin{tabular}{|llcc|}
\hline Species & Sediment & $\mathrm{r}_{\mathrm{s}} \mathrm{p}$ & Rep. ANOVA \\
\hline Anabaena sp. 1 & Profundal & $0.56, \mathrm{p}=0.004$ & $\mathrm{~ns}$ \\
& Littoral & $0.48, \mathrm{p}=0.015$ & \\
Anabaena solitaria & Profundal & $-0.54, \mathrm{p}=0.006$ & $\mathrm{~ns}$ \\
Klebahn & Littoral & $\mathrm{ns}$ & \\
Anabaena lemmermannii & Profundal & $0.86, \mathrm{p}<0.001$ & $\mathrm{~ns}$ \\
P Richter & Littoral & $0.904, \mathrm{p}<0.0001$ & \\
Asterionella formosa & Profundal & $\mathrm{ns}$ & $\mathrm{ns}$ \\
Hassall & Littoral & $0.894, \mathrm{p}<0.0001$ & \\
Ceratium hirundinella & Profundal & $-0.94, \mathrm{p}<0.0001$ & $\mathrm{p}<0.001$ \\
(O. F. Müller) Schrank & Littoral & $-0.789, \mathrm{p}<0.0001$ & \\
Microcystis botrys Teil & Profundal & $\mathrm{ns}$ & $\mathrm{ns}$ \\
& Littoral & $\mathrm{ns}$ & $\mathrm{n}$ \\
Microcystis wesenbergii & Profundal & $0.66, \mathrm{p}=0.0008$ & \\
(Komárek) Starmach & Littoral & $\mathrm{ns}$ & \\
\hline
\end{tabular}

Recruitment of Asterionella formosa from littoral sediments showed a very clear positive correlation with time $(0.894, \mathrm{p}<0.0001)$, while recruitment from the profundal had a low $\mathrm{r}_{\mathrm{s}}$ which was not significant. A similar pattern of low $\mathrm{r}_{\mathrm{s}}$ and no significance was found for Microcystis botrys recruitment, from both types of sediments.

For most taxa, there was no significant difference in recruitment between the 2 sediment types (littoral and profundal). However, recruitment of Ceratium hirundinella was significantly higher in the profundal sediments than the littoral sediments (repeated ANOVA, $\mathrm{p}<0.001$, Table 1).

\section{Treatment effect}

The presence of light had a positive effect on recruitment (Fig. 3, Table 2, ANOVA, p $\leq 0.01$ ) in all the species analyzed. These species included Anabaena sp. 1,
Anabaena solitaria, Anabaena lemmermannii, Asterionella formosa, and Ceratium hirundinella. The 2 Microcystis species included in the time effect analyses were not sufficiently abundant to analyze statistically for treatment effects. The filamentous cyanobacterial species and A. formosa had very little or no recruitment in the dark treatments (Fig. 3). In contrast, $C$. hirundinella recruited in both dark and light treatments had the largest recruitment $(5 \times$ higher than other treatments) in the dark treatment (at $17^{\circ} \mathrm{C}$ and with sediment mixing).

Sediment mixing enhanced recruitment in all species analyzed (Table 2, ANOVA, p < 0.001) (Fig. 3), except for Anabaena lemmermannii. Some variation can be observed among the different species. In $A$. solitaria for instance, there was little or no recruitment, unless the sediment was exposed to sediment mixing. In the other species, recruitment occurred in the non-mixed treatments but not to the same extent as in the samples with sediment mixing. Once again, Ceratium hirundinella differed from the cyanobacteria and Asterionella formosa, in that the effect of sediment mixing was significantly different from the other treatments only in the dark treatment at $17^{\circ} \mathrm{C}$.

High temperature $\left(17^{\circ} \mathrm{C}\right)$ appeared to enhance recruitment in most species (Fig. 3) but had a significant effect only in Anabaena lemmermannii (Table 2, ANOVA, $\mathrm{p}=0.01$ ). In fact, this species did not germinate at all at $7^{\circ} \mathrm{C}$ (Fig. 3). Ceratium hirundinella had little recruitment at $7^{\circ} \mathrm{C}$, while a 5 -fold higher recruitment occurred at $17^{\circ} \mathrm{C}$ (in darkness and with sediment mixing).

Sediment origin had a significant effect $(p \leq 0.01)$ on the recruitment of Anabaena lemmermannii and Ceratium hirundinella. However, in C. hirundinella, recruitment was larger from the profundal sediment,

Table 2. Effect of light, sediment mixing, temperature, and sediment origin, on the recruitment of 5 different species on Day 8. A 4-way ANOVA was performed on rank-transformed data. A logistic regression (Log. regr.) was performed on data that were transformed into 0 and 1, where 0 represented no recruitment and 1 was recruitment of any size. ns: not significant

\begin{tabular}{|c|c|c|c|c|c|c|c|c|}
\hline \multirow[t]{2}{*}{ Species } & \multicolumn{2}{|c|}{ Light } & \multicolumn{2}{|c|}{ Sediment mixing } & \multicolumn{2}{|c|}{ Temperature } & \multicolumn{2}{|c|}{ Sediment origin } \\
\hline & ANOVA & Log. regr. & ANOVA & Log. regr. & ANOVA & Log. regr. & ANOVA & Log. regr. \\
\hline Anabaena sp. 1 & $<0.01$ & 0.002 & $<0.001$ & $<0.05$ & ns & ns & ns & ns \\
\hline Anabaena solitaria & $<0.01$ & ns & $<0.001$ & $<0.05$ & ns & ns & ns & ns \\
\hline Anabaena lemmermannii & $<0.01$ & ns & ns & ns & 0.01 & ns & 0.01 & ns \\
\hline Asterionella formosa & $<0.01$ & $\mathrm{~ns}$ & $<0.001$ & ns & ns & ns & ns & ns \\
\hline Ceratium hiurndinella & $<0.01$ & 0.04 & $<0.001$ & $<0.05$ & ns & $\mathrm{ns}$ & $<0.001$ & $<0.05$ \\
\hline
\end{tabular}


while in $A$. lemmermannii recruitment exclusively occurred from the littoral sediment type.

Some noteworthy between-factors effects were found for Anabaena solitaria and Ceratium hirundinella. In A. solitaria, temperature alone had no significant effect on recruitment ( $p>0.05)$, while the interaction of temperature and light was significant $(p=0.01)$, as shown by a trend of higher recruitment at $17^{\circ} \mathrm{C}$ than at $7^{\circ} \mathrm{C}$ (Fig. 3). Similarly, temperature alone had no significant effect on the recruitment of $C$. hirundinella, while in combination with no light, temperature had a positive effect (temperature and light, $p<0.001$ ) on recruitment (Fig. 3).
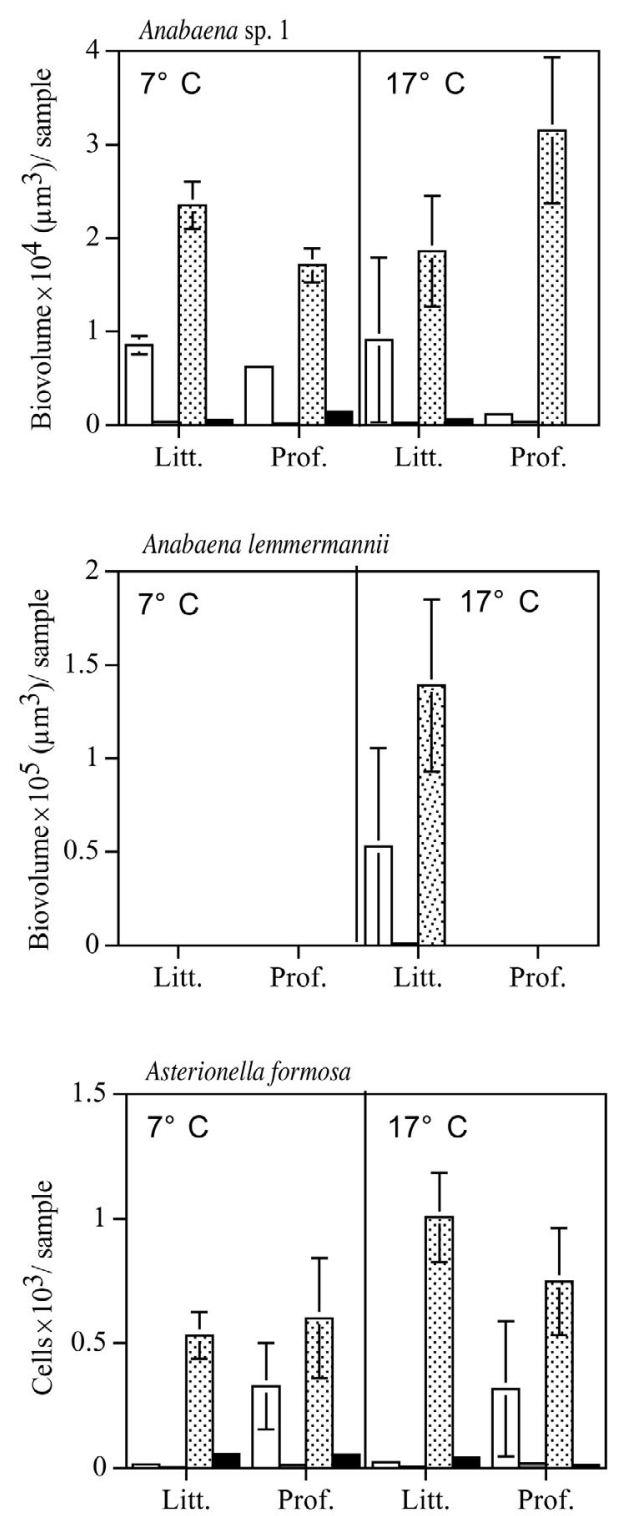

Logistic regression analyses were used to explore which factor(s) were important in determining recruitment versus no recruitment (Table 2). Sediment mixing turned out to be a significant factor (logistic regression, $\mathrm{p}<0.05)$ influencing recruitment in several species including Anabaena sp. 1, A. solitaria, and Ceratium hirundinella. Presence of light had a significant positive effect ( $p=0.002$ ) on recruitment of Anabaena sp. 1, while in C. hirundinella, darkness had a positive effect $(p=0.04)$. Sediment origin was a significant factor influencing the recruitment of $C$. hirundinella. Temperature had a positive significant effect only in $A$. lemmermannii.
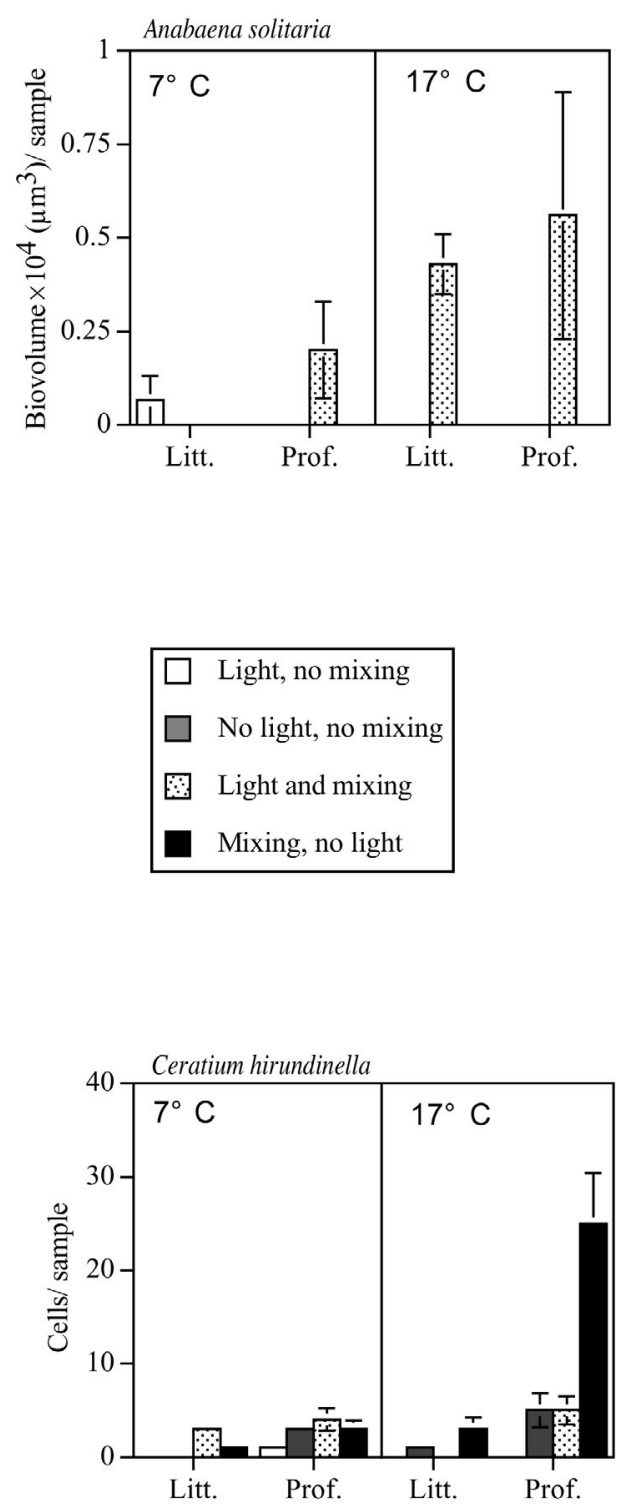

Fig. 3. Effect of temperature, sediment origin, light, and sediment mixing on the recruitment of phytoplankton benthic resting stages on Day 8. Each species is shown in 1 graph, split in 2 for the 2 temperature treatments. Littoral sediment origin is shown to the left in each panel and profundal sediments on the right. Recruitment is expressed as biovolume per sample for filamentous species, and as cells per sample for Asterionella formosa and Ceratium hirundinella. Error bars denote SE 

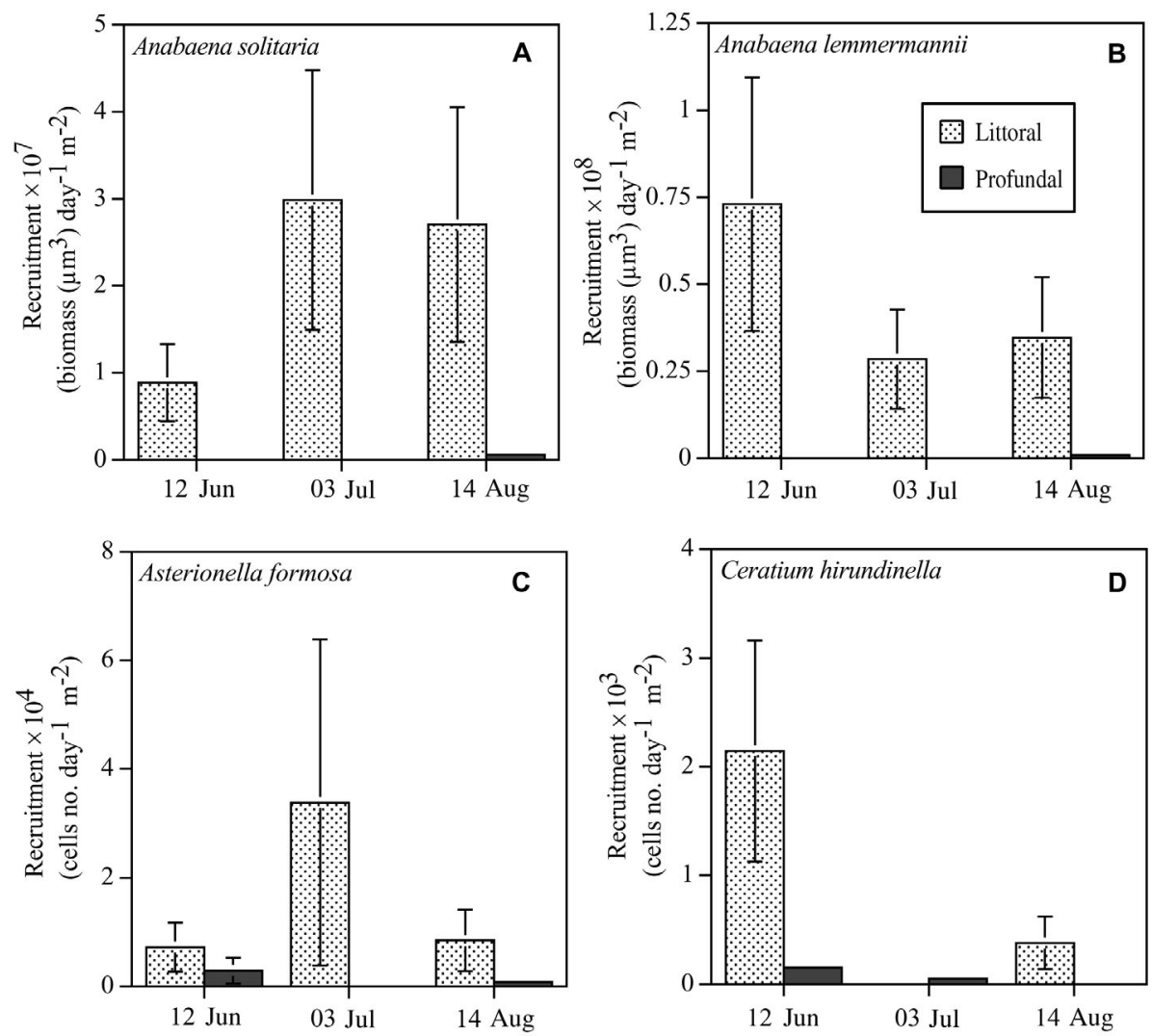

Fig. 4. Recruitment from lake sediments to recruitment traps. Light patterned bars denote littoral traps (1.5 m) while dark grey bars show profundal $(14 \mathrm{~m})$ traps. Recruitment is reported as biovolume in (A) and (B), while in (C) and (D) recruitment is reported as cells. Error bars denote SE

\section{Field recruitment experiments}

Three classes of phytoplankton dominated in the recruitment traps: cyanobacteria, diatoms, and dinoflagellates. Four representatives were chosen for analyses based on abundance: Anabaena solitaria, A. lemmermannii, Asterionella formosa, and Ceratium hirundinella. The overall picture was that recruitment occurred mostly from the littoral zone and throughout the entire summer season (mid-June to mid-August).

The 2 cyanobacterial species both had significantly higher recruitment at the littoral station compared to the profundal sampling station (repeated ANOVA, $\mathrm{p} \leq$ 0.01) (Fig. 4A,B). Recruitment occurred throughout the summer and there was no significant difference among the 3 sampling occasions. No recruitment occurred from the profundal site, except on the August sampling date, when a small number of filaments were found in the traps.

Asterionella formosa was found in the littoral recruitment traps throughout the summer (Fig. 4C). Little or no recruitment occurred at the profundal site. Statistical analyses showed that there was no effect of time, while the recruitment at the littoral site was signifi- cantly higher than at the profundal site (repeated ANOVA, $p=0.01$ ). In contrast to the cyanobacteria and diatoms, Ceratium hirundinella had a much higher recruitment at the beginning of the summer than at the end (Fig. 4D), although this difference was not significant in the test performed. However, the number of recruited individuals was substantially and significantly higher in the littoral than in the profundal zone (repeated ANOVA, $p=0.01$ ). These results were opposite to the laboratory experiment; i.e. recruitment was highest from the profundal sediment.

Light conditions naturally varied at the 2 sites, with light (60 to $800 \mu \mathrm{mol}$ photons $\mathrm{m}^{-2} \mathrm{~s}^{-1}$ ) reaching the sediment surface at the shallow site, whereas light was below detection at the $14 \mathrm{~m}$ site throughout the summer season. The $14 \mathrm{~m}$ site was anoxic $\left(0 \mathrm{mg} \mathrm{O} \mathrm{O}_{2} \mathrm{l}^{-1}\right)$ on the August sampling occasion only.

The phytoplankton counts showed that Ceratium hirundinella first appeared in plankton on 11 June and peaked on 24 July with a biomass of $430 \mu \mathrm{g}$ wet weight $\mathrm{l}^{-1}$ (Fig. 5A). After peaking the biomass dropped quickly, and by mid-August there were no more $C$. hirundinella cells in the plankton. Asterionella formosa occurred at low biomass throughout the sum- 

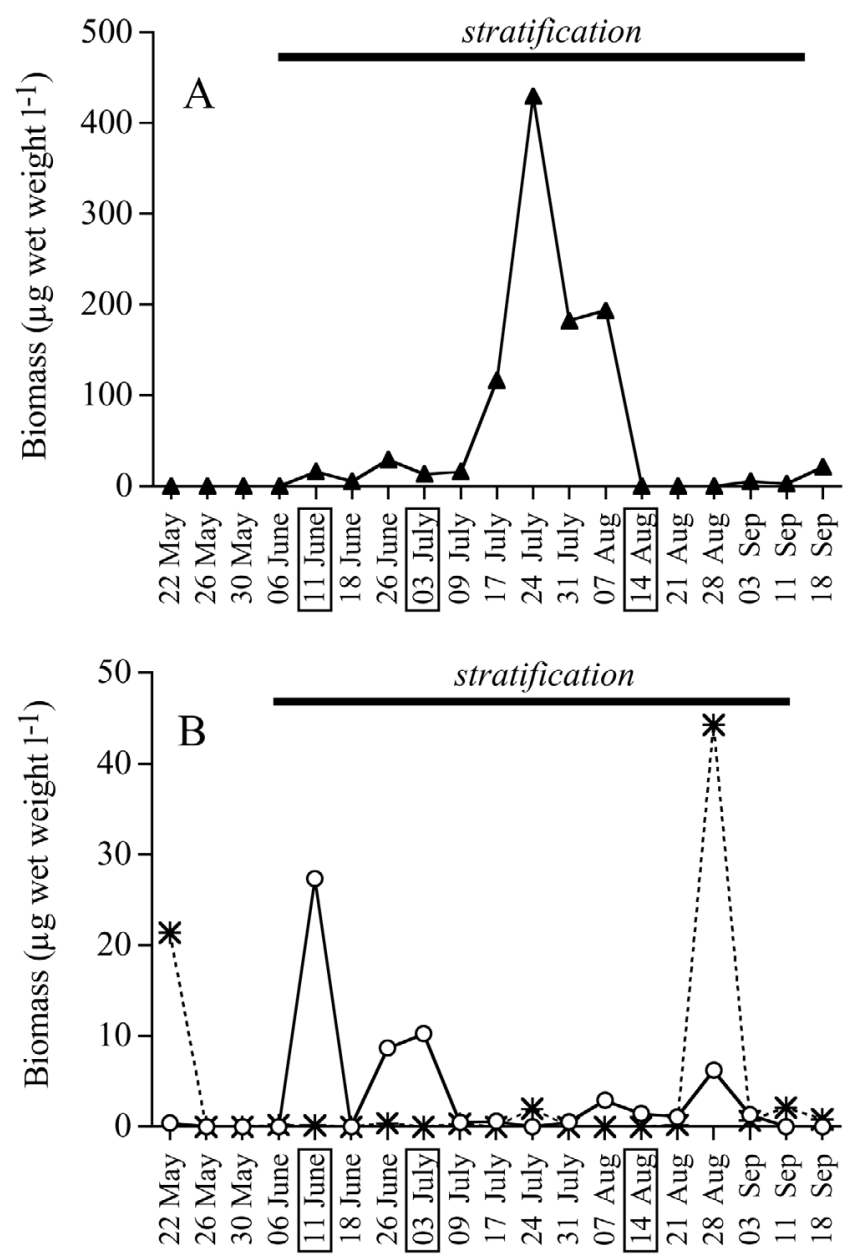

Time (dates)

Fig. 5. Phytoplankton dynamics of selected species in Lake Erken, May to September 2001, shown as biomass (wet weight). (A) Ceratium hirundinella (ム). (B) Anabaena spp. (O) and Asterionella formosa (*). Samples were taken from the entire water column during mixed periods ( 0 to $20 \mathrm{~m}$ ) and in the epilimnion ( 0 to $10 \mathrm{~m}$ ) during summer stratification. Horizontal bar above (A) and (B) indicates the extent of the stratified period. Dates surrounded by boxes are the dates corresponding to germination trap sampling

mer with a small peak on 28 August (Fig. 5B). Anabaena spp. biomass was generally low, except for on a few occasions in June and July (Fig. 5B).

\section{DISCUSSION}

We propose that the littoral zone is more important than the profundal as a site of phytoplankton (including cyanobacteria, diatoms, and dinoflagellates) resting stage recruitment based on the combined results from our field and laboratory experiments. Although the profundal sediments may act as an equally large potential 'seed bank' as the littoral, the conditions in the littoral zone are much more conducive to recruitment from phytoplankton resting cells. Our field experiments showed that recruitment was larger at the littoral site. Furthermore, the laboratory experiment showed that light, sediment mixing, and high temperature (all characteristics of the littoral zone) stimulated recruitment.

As expected, light was an important factor regulating the recruitment of all species analyzed. In the cyanobacterial species and the diatom, there was little or no recruitment in the dark treatments (Fig. 3). Both cyanobacterial akinetes (e. g. Huber 1985, van Dok \& Hart 1997) and diatom resting stages (Hollibaugh et al. 1981) require light in order to germinate. However, there is some evidence that akinetes provided with suitable organic carbon can germinate in the dark (van Dok \& Hart 1997). The lag phase prior to recruitment of Anabaena sp. 1 and A. lemmermannii has been observed in other akinete-forming species, for example Gloeotrichia echinulata (Barbiero 1993, Karlsson 2003, Karlsson-Elfgren et al. 2004). The akinete must mature, germinate, and gas vesicles must form prior to recruitment (Wildman et al. 1975). Although Asterionella formosa also needs light in order to germinate, this species does not form morphologically differentiated resting propagules (Lund 1954, Sicko-Goad et al. 1989). Presumably, physiological resting stages germinate quicker than, for example akinetes (suggested by findings of Sicko-Goad et al. 1986, who found that complete rejuvenation of Melosira granulata occurred in less than $24 \mathrm{~h}$ ). However, our time course experiment showed increased recruitment with time in $A$. formosa. This increase could be due to growth on the sediment surface, a common feature of diatoms. Although some cells and filaments of $A$. formosa and Anabaena spp. could occasionally be found in the dark treatments, these were found in extremely low numbers. An explanation is that these cells were not viable, or still in their resting stage, and had been resuspended during sampling. Alternatively, they could have been induced by the red light used during sampling.

A surprising finding was that cells of Asterionella formosa were found in treatments exposed to light but no sediment mixing. Since diatoms have neither flagella nor gas vesicles, we did not expect to find them in the water overlaying the undisturbed sediments. However, many marine species are able to achieve positive buoyancy, e.g. Richardson et al. (1996), possibly by regulating internal carbohydrate concentration (Richardson \& Cullen 1995) or through ionic regulation of intracellular regulating osmolytes, especially nitrates (Villareal et al. 1993) and quaternary ammonium derivatives (Boyd \& Gradmann 2002). In freshwater diatoms, live cells are known to have a lower 
sinking rate than dead ones (Heaney \& Butterwick 1985) and nutrient deficiency in A. formosa has been shown to increase its sinking rate (Davey 1988). To date, positive buoyancy has not been described for freshwater diatoms. The A. formosa cells encountered in our samples were healthy-looking, i.e. they had several chloroplasts and were not infested with phototactic choanoflagellates. Our data possibly suggests that newly germinated $A$. formosa cells may have a slight positive buoyancy, perhaps mediated by some form of ionic regulation, to help them become entrained in the water and thereby be transported upwards in the water column. At this point, however, these are speculations, as we cannot rule out other explanations.

Sediment mixing was the next most important factor regulating recruitment in cyanobacteria, the diatom, and the dinoflagellate. Sediment mixing (bioturbation or physical resuspension) allows resting propagules that have been buried too deep to be exposed to incoming light, to be brought to the illuminated sediment surface and, plausibly, to the water phase. Also, sediment mixing may relieve resting propagules from anoxia which is a factor that prevents recruitment in some dinoflagellates (Rengefors \& Anderson 1998). Consequently, the effect of sediment mixing is to increase the number of resting propagules that can germinate. A recent study by Ståhl-Delbanco \& Hansson (2002) showed that bioturbation greatly enhanced the recruitment of Anabaena spp., Microcystis spp. and Gonyostomum semen. Of the 2 types of bioturbating invertebrates studied, Asellus aquaticus (Isopoda) had a much greater effect than chironomids. StåhlDelbanco \& Hansson (2002) also noted that bioturbation by $A$. aquaticus occurred much deeper into the sediments than of the chironomids. Thus, a larger number of more deeply buried resting propagules probably had the chance to germinate in the A. aquaticus treatment. It must also be noted, however, that bioturbating invertebrates may also have a negative impact on germination. For example, they play an important role in carrying resting propagules down into the sediment deposits as shown by the classical study of Stockner \& Lund (1970). Furthermore, diatom resting stages may be grazed by benthic animals (Gibson et al. 2003). Another effect of sediment mixing is that substances important for phytoplankton growth (e.g. nutrients) can be released to the water and possibly stimulate recruitment rate. Gibson et al. (2000), for instance, found that the internal cycling of silica, a prerequisite for diatom growth, was enhanced by bioturbation.

The importance of sediment mixing and light for recruitment in the laboratory experiment corresponds well with the recruitment patterns observed in the field and with the biotic and abiotic conditions in Lake
Erken. In the 4 species analyzed in the field (Anabaena solitaria, A. lemmermannii, Asterionella formosa, Ceratium hirundinella) and at all dates, the recruitment was significantly higher at the littoral station. Little or no recruitment occurred at the deep site, where light was below detection. Thus, it is unlikely that any substantial recruitment should take place, unless physical resuspension occurs. Studies from Lake Erken show that sediment down to $12 \mathrm{~m}$ depth $(60 \%$ of the sediment area) can be resuspended by wind action (Weyhenmeyer 1996). In addition, the shallow sites in Lake Erken are dominated by benthic Crustacea, especially Gammarus sp. and Asellus aquaticus (Andersson 1974), suggesting that bioturbation is high at the littoral site. Consequently, bioturbation in the littoral could have a positive effect on resting cell recruitment (Ståhl-Delbanco \& Hansson 2002). In contrast, chironomids and oligochaetes dominate the deep site (Sandberg 1969). Once again, previous studies (StåhlDelbanco \& Hansson 2002) indicate that there are no beneficiary effects of chironomids on recruitment.

Although temperature is often cited as an important factor in regulating germination, in our analyses, temperature alone was only significant in the recruitment of Anabaena lemmermannii. Most cyanobacteria are known to grow poorly at low temperatures (Fogg 1963). Apparently, A. lemmermannii will not recruit at temperatures as low as $7^{\circ} \mathrm{C}$. Species-specific differences in optimum germination temperature corresponding to differences in optimum growth temperatures have been found in other Anabaena species (Baker \& Bellifemine 2000). However, temperature in combination with other factors (such as light) had a significant positive effect on recruitment in Anabaena solitaria and Ceratium hirundinella, indicating that temperature nonetheless plays an important role in recruitment.

In contrast to the cyanobacteria and the diatom, Ceratium hirundinella did not require light to germinate. In fact, the largest recruitment was found in the dark plus sediment mixing treatment $\left(17^{\circ} \mathrm{C}\right.$ and profundal sediment). This apparently odd feature of C. hirundinella can be easily explained based on findings in previous studies. First, recruitment was small in the $7^{\circ} \mathrm{C}$ treatment since this is the minimum temperature at which germination takes place (Rengefors \& Anderson 1998). Second, the recruitment was low in the light at $17^{\circ} \mathrm{C}$ as most of the cyst 'seed bank' (cysts found on sediment) had already been exhausted by Day 8 (Fig. 2), when the 'treatment' analysis was performed. C. hirundinella is known to germinate quickly (within $24 \mathrm{~h}$ ) at $17^{\circ} \mathrm{C}$ (Rengefors \& Anderson 1998). Accordingly, if the 'treatment' analysis had been performed on an earlier date, the outcome would have been different. C. hirundinella cells have been shown to ger- 
minate in complete darkness (Rengefors \& Anderson 1998), although at a slower rate than in light. Consequently, a large cyst seed bank remained on Day 8 in the dark, and with sediment mixing recruitment was further enhanced, resulting in a recruitment 5-fold higher than in the other treatments. Hence, the effect of sediment mixing in $C$. hirundinella dark treatments cannot be explained by the fact that sediment mixing exposes cells to light. A possible explanation is oxygenation of the sediment, since it has been shown that C. hirundinella cysts will not germinate in completely anoxic conditions (Rengefors \& Anderson 1998). It is possible that low oxygen microclimates may have developed underneath the sediment surface in the test tubes, although no measurements were made to support this explanation.

Recruitment patterns with respect to time differed among the species analyzed, revealing that the time of response (i.e. recruitment) varies among species and may in turn be tightly coupled to seasonal succession. Timing of germination has been suggested to play an important role in the seasonal succession of diatoms (McQuoid \& Hobson 1995) and has been shown to be important in freshwater dinoflagellates (Rengefors 1998, Rengefors \& Anderson 1998, Rengefors et al. 1998). Within the same cyanobacterial genus, Anabaena, we observed completely different patterns of recruitment. For instance, A. solitaria germinated immediately when exposed to light, sediment mixing, and $17^{\circ} \mathrm{C}$. Recruitment was high at the start and dropped with time, indicating that the 'seed bank' was diminishing. These results are in agreement with Cmiech et al. (1984), who showed that recruitment in A. solitaria started after only $24 \mathrm{~h}$, and that $40 \%$ of the akinetes had germinated after $7 \mathrm{~d}$. In contrast, $\mathrm{A}$. lemmermannii had its maximum recruitment towards the end of the incubation period. Similar to the Anabaena species, the 2 Microcystis species also had different response patterns with staggered germination times (Fig. 2). In accordance with our results, $M$. wesenbergii was also found to be slow germinating and growing resulting in high abundance towards the end of the summer in a field study in eutrophic Lake Limmaren, Sweden (Brunberg \& Blomqvist 2003).

A pattern with high initial recruitment was observed in Ceratium hirundinella, which has the ability to germinate quickly and establish a planktonic population given the right conditions. The analysis of recruitment versus time showed that recruitment was highest at the beginning, dropped quickly and ceased completely by Day 16. These results concur with those of Rengefors \& Anderson (1998), who showed that mature cysts can germinate in 1 to $2 \mathrm{~d}$ and that $95 \%$ of the cysts germinate at temperatures above $11^{\circ} \mathrm{C}$. Thus, the rapid decline of $C$. hirundinella in the samples can be ex- plained by an exhaustion of the cyst 'seed bank' which agrees with field data showing that most cysts germinate in May and June (Rengefors 1998). The trap data also showed a similar pattern with highest recruitment in the beginning of the summer.

The germination trap data and phytoplankton counts showed complimentary patterns for Ceratium hirundinella. High recruitment was found on the 12 June sampling occasion, corresponding with the time when C. hirundinella was first seen in the water (Fig. 5A). By 3 July recruitment had ceased, but an exponentially growing population had apparently been established in the water column. The smaller recruitment from the littoral site observed in mid-August might explain the cells detected in the September samples. Asterionella formosa population dynamics during the summer cannot be explained by recruitment patterns, presumably because the stratified summer conditions were not conducive to vegetative growth in this species. The recruitment pattern of Anabaena spp. showed recruitment from the littoral throughout the summer. The pelagic was thus presumably seeded with inocula; however, the phytoplankton counts showed that Anabaena spp. never dominated the phytoplankton community.

Whether the littoral or the profundal sediments have the largest seed bank potential has been much discussed in literature dealing with phytoplankton resting stages. There are really 2 issues to be considered here. One is the actual number of viable propagules present ('seed bank' potential) and the second is whether these are likely to have the chance to germinate (actual 'seed bank'). In our laboratory experiments, we found that sediment origin was not a significant factor influencing recruitment in most species, indicating no difference in the 'seed bank' potential of the 2 sediment types. However, in Ceratium hirundinella there was a significant difference between littoral and profundal sediments. The profundal sediments likely contained more viable dinoflagellate cysts than the same volume of littoral sediment as shown by the difference in total number of cells germinated from the profundal sediments compared to the littoral. This, in turn, agrees with the findings in Rengefors (1998), showing that cyst numbers in profundal sediments were 10 times higher than in shallow sediments $(4 \mathrm{~m})$ in Lake Erken. The lake bottom at $14 \mathrm{~m}$ and below is known as a region of particle accumulation in the sediments of Lake Erken (Weyhenmeyer et al. 1997), which explains why cyst numbers probably are higher in these areas. Other resting spores presumably also accumulate in these regions, but may have low germination rates, as found in Gloeotrichia echinulata (Forsell \& Pettersson 1995). Also, dinoflagellate cysts are extremely resistant and can remain viable in the sediments for several decades (McQuoid et al. 
2002). Nevertheless, the recruitment traps show that most actual recruitment took place in the littoral despite the lower potential cyst/seed bank (Rengefors 1998). Higher irradiance and sediment mixing (bioturbation) at the shallow sites, as well as slightly higher temperature can in turn explain this important result. In addition, the $14 \mathrm{~m}$ site was anoxic in August, which can further explain why, for instance, $C$. hirundinella did not germinate from this site at that time. Thus, it seems like littoral sediments are the most important actual 'seed banks' in a lake and provide much of the inocula for planktonic blooms as suggested by Hansson et al. (1994). These results are further supported by the similar studies on cyanobacterial species, including Microcystis spp. (Brunberg \& Blomqvist 2003) and G. echinulata (Karlsson-Elfgren et al. 2004).

To conclude, our field data from the recruitment traps, together with the results from the laboratory experiment, support our hypothesis that the littoral sediments are the most important 'seed banks' in a lake and provide the inocula for planktonic blooms. Based on the extent of recruitment in the laboratory, the potential 'seed bank' of the profundal zone is equally large as the littoral sediment, but due to environmental conditions (low light, low sediment mixing), little or no recruitment occurs from these areas. In the littoral zone, on the other hand, light reaches the sediment surface throughout the summer, sediment mixing is high and the water temperature is periodically higher than in the profundal. The most important factors initiating and enhancing recruitment in the laboratory were light and sediment mixing. Sediment mixing was not necessary for, but greatly enhanced recruitment of all the species, while light was necessary for both cyanobacteria and diatom recruitment. Finally, temperature and sediment origin also had a positive effect on the recruitment of some species especially in combination with other factors. Questions that remain to be answered are to what extent the sediment inocula contribute to the initiation and growth of pelagic populations, and whether profundal 'seed banks' are lost as inocula or can be germinated due to physical resuspension and mixing.

Acknowledgements. We thank the staff at the Erken Laboratory and Dr. K. Pettersson for providing background physical and chemical data, lending us boats, and scuba divers. Dr. J. Padisak is acknowledged for phytoplankton counts. Thanks also to Dr. I. Karlsson-Elfgren for collecting sediment samples and for discussions. Drs. O. Olsson and M. McQuoid are thankfully acknowledged for statistical advice. Dr. G. Cronberg is gratefully acknowledged for identifying the cyanobacterial species. Finally, we thank Dr. M. McQuoid, the BenthicPelagic Research group at Lund University, and several anonymous reviewers for comments on the manuscripts. This study was funded by Stiftelsen Oscar och Lilli Lamms Minne.
A.S.-D. is also grateful for financial support from MISTRA, through the VASTRA program.

\section{LITERATURE CITED}

Anderson DM, Keafer BA (1985) Dinoflagellate cyst dynamics in coastal and estuarine waters. In: Anderson DM, White AW, Baden DG (eds) Toxic dinoflagellates. Proc 3rd Int Conf. Toxic Dinoflagellates, St. Andrews, NB, June 8-12, 1985. Elsevier Science, New York, p 219-224

Anderson DM, Keafer BA (1987) An endogenous annual clock in the toxic marine dinoflagellate Gonyaulax tamarensis. Nature 325:616-617

Anderson DM, Wall D (1978) Potential importance of benthic cysts of Gonyaulax tamarensis and G. excavata in initiating toxic dinoflagellate blooms. J Phycol 14: $224-234$

Anderson DM, Chisholm SW, Watras CJ (1983) Importance of life cycle events in the population dynamics of Gonyaulax tamarensis. Mar Biol 76:179-189

Anderson DM, Coats DW, Tyler MA (1985) Encystment of the dinoflagellate Gyrodinium uncatenum: temperature and nutrient effects. J Phycol 21:200-206

Anderson DM, Taylor CD, Armbrust EV (1987) The effects of darkness and anaerobiosis on dinoflagellate cyst germination. Limnol Oceanogr 32:340-351

Andersson E (1974) Limnological studies of the 'river lake' Pajep Måskejaure in southern Sweden. PhD thesis, Department of Limnology, Uppsala University, Uppsala

Baker PD, Bellifemine D (2000) Environmental influences on akinete germination of Anabaena circinalis and implication for management of cyanobacterial blooms. Hydrobiologia 427:65-73

Barbiero RP (1993) A contribution to the life history of the planktonic cyanophyte, Gloeotrichia echinulata. Arch Hydrobiol 127:87-100

Barbiero RP, Welch EB (1992) Contribution of benthic bluegreen algal recruitment to lake populations and phosphorus translocation. Freshw Biol 27:249-260

Blomqvist P, Pettersson A, Hyenstrand P (1994) Ammoniumnitrogen: a key regulatory factor causing dominance of non-nitrogen fixing cyanobacteria in aquatic systems. Arch Hydrobiol 132:141-164

Boero F, Belmonte G, Fanelli G, Piraino S, Rubino F (1996) The continuity of living matter and the discontinuities of its constituents: do plankton and benthos really exist? TREE 11:177-179

Boyd CM, Gradmann D (2002) Impact of osmolytes on buoyancy of marine phytoplankton. Mar Biol 141:605-618

Brunberg AK, Blomqvist P (2003) Recruitment of Microcystis (Cyanophyceae) from lake sediments: the importance of littoral inocula. J Phycol 39:58-63

Cáceres CE (1998) Interspecific variation in the abundance, production, and emergence of Daphnia diapausing eggs. Ecology 79:1699-1710

Cmiech HA, Reynolds CS, Leedale GF (1984) Seasonal periodicity, heterocyst differentiation and sporulation of planktonic cyanophyceae in a shallow lake, with special reference to Anabaena solitaria. Br Phycol J 19:245-257

Conover WJ, Iman RL (1981) Rank transformations as a bridge between parametric and nonparametric statistics. Am Stat 35:124-129

Dale B (1983) Dinoflagellate resting cysts: 'benthic plankton'. In: Fryxell GA (ed) Survival strategies of the algae. Cambridge University Press, Cambridge, p 69-137

Davey MC (1988) The effects of nutrient depletion on the 
sinking velocity and cellular composition of a freshwater diatom. Arch Hydrobiol 112:321-334

Fogg GE (1963) The role of algae in organic production in aquatic environments. Br Phycol Bull 2:195-205

Forsell L (1998) Migration from the littoral zone as an inoculum for phytoplankton. Arch Hydrobiol Spec Iss Adv Limnol 51:21-27

Forsell L, Pettersson K (1995) On the seasonal migration of the cyanobacterium Gloeotrichia echinulata in Lake Erken, Sweden, and its influence on the pelagic population. Mar Freshw Res 46:287-293

Fryxell GA (1983) Survival strategies of the algae. Cambridge University Press, Cambridge

Gibson CE, Fitzsimons AG (1990) Induction of the resting phase in the planktonic diatom Aulacoseira subarctica in very low light. Br Phycol J 25:329-334.

Gibson CE, Wang G, Foy RH (2000) Silica and diatom growth in Lough Neagh: the importance of internal recycling. Freshw Biol 45:285-293

Gibson CE, Anderson NJ, Haworth EY (2003) Aulacoseira subacrtica: taxonomy, physiology, ecology and palaeoecology. Eur J Phycol 38:83-101

Hairston NGJ (1998) Time travelers: What's timely in diapause research. Arch Hydrobiol Spec Iss Adv Limnol 52: $1-15$

Hairston NGJ, Cáceres CE (1996) Distribution of crustacean diapause: micro- and macroevolutionary pattern and process. Hydrobiologia 320:27-44

Hairston NGJ, Hansen AM, Schaffner WR (2000) The effect of diapause emergence on the seasonal dynamics of a zooplankton assemblage. Freshw Biol 45:133-145.

Håkansson L (1978) Erken - morfometri. Scripta Limnologica Upsaliensia, Institute of Limnology, Uppsala University, Uppsala

Hansson LA (1993) Factors initiating algal life-form shift from sediment to water. Oecologia 94:286-294

Hansson LA (1996a) Behavioural response in plants: adjustment in algal recruitment induced by herbivores. Proc $\mathrm{R}$ Soc Lond 263:1241-1244

Hansson LA (1996b) Algal recruitment from lake sediments in relation to grazing, sinking, and dominance patterns in the phytoplankton community. Limnol Oceanogr 41: 1312-1323

Hansson LA, Rudstam LG, Johnson TB, Soranno P, Allen Y (1994) Patterns in algal recruitment from sediment to water in a dimictic, eutrophic lake. Can J Fish Aquat Sci 51:2825-2833

Head RM, Jones RI, Bailey-Watts AE (1999) An assessment of the influence of recruitment from the sediment on the development of planktonic populations of cyanobacteria in a temperate mesotrophic lake. Freshw Biol 41:759-769

Heaney SI, Butterwick C (1985) Comparative mechanisms of algal movement in relation to phytoplankton production. In: Rankin MA, Checkley D, Cullen J, Kitting C, Thomas P (eds) Migration: mechanisms and adaptive significance. Contribution in Marine Science Supplement 27. University of Texas, Port Aransas, TX, p 114-134

Heaney SI, Chapman DV, Morison HR (1983) The role of the cyst stage in the seasonal growth of the dinoflagellate Ceratium hirundinella within a small productive lake. Br Phycol J 18:47-59

Hollibaugh JT, Seibert DLR, Thomas WH (1981) Observations on the survival and germination of resting spores of 3 Chaetoceros (Bacillariophyceae) species. J Phycol 17:1-9

Huber AL (1985) Factors affecting the germination akinetes of Nodularia spumigena (Cyanobacteriaceae). Appl Environ Microbiol 49:73-78
Huber G, Nipkow F (1923) Experimentelle Untersuchungen über Entwicklund und Formbildung von Ceratium hirundinella O. F. Müller. Flora (Jena) 116:114-215

Karlsson, I (2003) Benthic growth of Gloeotrichia echinulata. Hydrobiologia 506:189-196

Karlsson-Elfgren I, Rengefors K, Gustafsson S (2004) Factors regulating recruitment to the water column in the bloomforming cyanobacterium Gloeotrichia echinulata. Freshw Biol 49:265-273

Kremp A, Anderson, DM (2000) Factors regulating germination of resting cysts of the spring bloom dinoflagellate Scrippsiella hangoei from the northern Baltic Sea. J Plankton Res 22:1311-1327

Kremp A, Shull DH, Anderson DM (2003) Effects of depositfeeder gut passage and fecal pellet encapsulation on germination of dinoflagellate resting cysts. Mar Ecol Prog Ser 263:65-73

Lund JWG (1954) The seasonal cycle of the plankton diatom Melosira italica (Epr.) Kütz, subsp. subarctica O. Müll. J Ecol 42:141-179

McQuoid MR, Hobson LA (1995) Importance of resting stages in diatom seasonal succession. J Phycol 31:44-50

McQuoid MR, Hobson LA (1996) Diatom resting stages. J Phycol 32:889-902

McQuoid M, Godhe A, Nordberg K (2002) Viability of phytoplankton resting stages in the sediments of a coastal Swedish fjord. Eur J Phycol 37:191-201

Nauwerck A (1963) Die Beziehungen zwischen Zooplankton und Phytoplankton im See Erken. Symbolae Botanicae Upsalienses 17:1-163

Olli K (1996) Resting cyst formation of Eutreptiella gymnastica (Euglenophyceae) in the northern coastal Baltic Sea. J Phycol 32:535-542

Pettersson K (1985) The availability of phosphorus and the species composition of the spring phytoplankton in Lake Erken. Int Rev Ges Hydrobiol 70:527-546

Pollingher U, Bürgi HR, Ambühl H (1993) The cysts of Ceratium hirundinella. Their dynamics and role within a eutrophic (Lake Sempach, Switzerland). Aquat Sci 1: $10-18$

Rengefors K (1998) Seasonal succession of dinoflagellates coupled to the benthic cyst dynamics in Lake Erken, Sweden. Arch Hydrobiol Spec Iss Adv Limnol 51:123-141

Rengefors K, Anderson DM (1998) Environmental and endogenous regulation of cyst germination in relation to seasonal succession of 2 fresh-water dinoflagellates. J Phycol 34:568-577

Rengefors K, Karlsson I, Hansson LA (1998) Algal cyst dormancy-a temporary escape from herbivory. Proc R Soc Biol Sci Ser B 265:1353-1358

Richardson TL, Cullen JJ (1995) Changes in buoyancy and chemical composition during growth of a coastal marine diatom: ecological and biogeochemical consequences. Mar Ecol Prog Ser 128:77-90

Richardson TL, Ciotti A, Cullen JJ, Villareal TA (1996) Physiological and optimal properties of Rhizosolenia formosa (Bacillariophyceae) in the context of open-ocean vertical migration. J Phycol 32:741-757

Sandberg G (1969) A quantitative study of chironomid distribution and emergence in Lake Erken. Arch Hydrobiol Spec Iss Adv Limnol 35:119-201

Sanderson BL, Frost TM (1996) Regulation of dinoflagellate populations: relative importance of grazing, resource limitation, and recruitment from sediments. Can J Fish Aquat Sci 53:1409-1417

Sandgren CD (1983) Survival strategies of chrysophycean flagellates: reproduction and the formation of resistant rest- 
ing cysts. In: Fryxell GA (ed) Survival strategies of the algae. Cambridge University Press, Cambridge, p 23-48 Schindler DE, Scheurell MD (2002) Habitat coupling in lake ecosystems. Oikos 98:177-189

Sicko-Goad L, Stoermer EF, Fahnenstiel G (1986) Rejuvenation of Melosira granulata (Bacillariophyceae) resting cells from the anoxic sediments of Douglas Lake, Michigan. I. Light microscopy and ${ }^{14} \mathrm{C}$ uptake. J Phycol 22:22-28

Sicko-Goad L, Stoermer EF, Kociolek JP (1989) Diatom resting cell rejuvenation and formation: time course, species records and distribution. J Plankton Res 11:375-389

Sommer U, Gliwicz M, Lampert W, Duncan A (1986) The $\mathrm{PEG}^{*}$-model of seasonal succession of planktonic events in fresh waters. Arch Hydrobiol 106:433-471

Ståhl-Delbanco A, Hansson LA (2002) Effects of bioturbation on recruitment of algal cells from the 'seed bank' of lake sediments. Limnol Oceanogr 47:1836-1843

Stockner JG, Lund JWG (1970) Live algae in postglacial lake deposits. Limnol Oceanogr 15:41-58

Editorial responsibility: Paul Harrison, Kowloon, Hong Kong van Dok W, Hart BT (1997) Akinete germination in Anabaena circinalis (Cyanophyta). J Phycol 33:12-17

Villareal T, Altabet MA, Culver-Rymsza K (1993) Nitrogen transport by vertically migrating diatom mats in the North Pacific Ocean. Nature 363:709-711

Weyhenmeyer GA (1996) The influence of stratification on the amount and distribution of different settling particles in Lake Erken. Can J Fish Aquat Sci 53:1254-1262

Weyhenmeyer GA (1999) Lake Erken-meteorological, physical, chemical and biological data and a list of publications from 1933 to 1998. Scripta Limologica Upsaliensa, Department of Limnology, Uppsala University, Uppsala

Weyhenmeyer GA, Håkanson L, Meili M (1997) A validated model for daily variations in the flux, origin and distribution of settling particles within lakes. Limnol Oceanogr 42: $1517-1529$

Wildman RB, Loescher JH, Winger CL (1975) Development and germination of akinetes of Aphanizomenon flosaquae. J Phycol 11:96-104

Submitted: January 5, 2004; Accepted: June 14, 2004 Proofs received from author(s): September 10, 2004 